\title{
Effect of Antioxidant Supplementation on Markers of Oxidative Stress and Muscle Damage after Strength Exercise: A Systematic Review
}

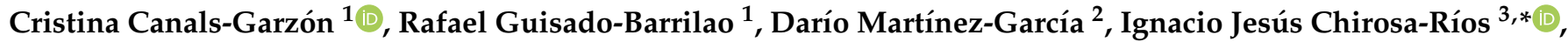 \\ Daniel Jerez-Mayorga ${ }^{2}$ (i) and Isabel María Guisado-Requena ${ }^{4}(1)$
}

1 Department of Exercise Medicine, Cardiovascular Risk and Rehabilitation, Faculty of Health Sciences, University of Granada, 18016 Granada, Spain; nevada1755@hotmail.com (C.C.-G.); rguisado@ugr.es (R.G.-B.)

2 Faculty of Rehabilitation Sciences, Universidad Andres Bello, Concepción 7591538, Chile; damaga1991@gmail.com (D.M.-G.); daniel.jerez@unab.cl (D.J.-M.)

3 Department of Physical Education and Sports, Faculty of Sport Sciences, University of Granada, 18011 Granada, Spain

4 Departament of Nursing, Physiotherapy and Occupational Therapy, Faculty of Nursing, Group of Preventive Activities in the University Health Sciences Setting, University of Castilla-La Mancha (Universidad de Castilla-La Mancha/UCLM), 02071 Albacete, Spain; isabelm.guisado@uclm.es

* Correspondence: ichirosa@ugr.es; Tel.: +34-639-646962

check for updates

Citation: Canals-Garzón, C.; Guisado-Barrilao, R.; Martínez-García, D.; Chirosa-Ríos, I.J.; Jerez-Mayorga, D.; Guisado-Requena, I.M. Effect of Antioxidant Supplementation on Markers of Oxidative Stress and Muscle Damage after Strength Exercise: A Systematic Review. Int. J. Environ. Res. Public Health 2022, 19, 1803. https://doi.org/10.3390/ ijerph19031803

Academic Editor: Ana De Fátima Pereira

Received: 9 December 2021

Accepted: 31 January 2022

Published: 5 February 2022

Publisher's Note: MDPI stays neutral with regard to jurisdictional claims in published maps and institutional affiliations.

Copyright: (C) 2022 by the authors. Licensee MDPI, Basel, Switzerland. This article is an open access article distributed under the terms and conditions of the Creative Commons Attribution (CC BY) license (https:// creativecommons.org/licenses/by/ $4.0 /)$.

\begin{abstract}
Background: The purpose of this systematic review was to determine the effect of antioxidant consumption on markers of oxidative stress and muscle damage after performing a muscle strength exercise. Methods: The Preferred Reporting Items for Systematic Review and Meta-Analyses (PRISMA) statements were followed. Four databases were used: Scopus, PubMed, WOS and SportDiscus. Methodological quality was assessed using the PEDro scale. Results: A total of 1709 articles were retrieved and following duplicate removal and application of exclusion criteria seven articles were reviewed. Supplementation with pomegranate juice alleviates oxidative stress, taurine reduces muscle damage, melatonin protects the skeletal muscles, blueberries decrease oxidation and oats mitigate muscle damage. Conclusions: Acute administration of antioxidants immediately before or during an exercise session can have beneficial effects, such as delay of fatigue and a reduction in the recovery period. Administration of antioxidant susbtances may reduce muscle damage and oxidative stress markers.
\end{abstract}

Keywords: strength training; oxidative stress; muscle damage; free radicals; antioxidants

\section{Introduction}

Physical training programmes are based on provoking a state of transient fatigue, thus increasing the body's regenerative capacity and inducing overcompensation of the biological systems involved [1]. Specifically, strenuous exercise, defined as any activity that expends six metabolic equivalents (METS) per minute or more, causes structural damage to muscle cells, leading to pain and swelling, increased free radicals, impaired immune function and the removal of proteins from circulation, among other consequences [2-4]. These processes have various clinical manifestations, including inflammation and immunosuppression, which heightens vulnerability to infection [1].

Therefore, if the imbalance between the work and recovery phases is prolonged, the organism may be unable to adapt properly to the physical workload. The resulting state of excess training has negative consequences not only for physical performance but also for health [1] and when this state occurs, reactive oxygen species (ROS) are synthesised in the body [5,6]. Many studies have focused on ROS, but it is only now that the essential role they play in cell equilibrium and homeostasis is beginning to be understood [6,7], they also intervene in muscle contraction, provoking adaptive responses in muscle fibres [6]. 
Recent studies, such as Torre et al. [8] and Fang and Nasir [9], have shown that ROS induced by physical exercise can regulate enzymatic and non-enzymatic antioxidants in the biological system. Therefore, exercise could be an optimiser of ROS, preventing cellular oxidative damage, and these molecules also provide a signal for muscle adaptation $[10,11]$. Moreover, they act as molecular messengers, interacting with proteins that are sensitive to the oxidation-reduction reactions (REDOX) that regulate different processes in the body, such as insulin sensitivity, growth factor signalling, vasodilation and immune response [8].

Exercise may also produce alterations in the immune system, as neutrophils enter the damaged tissue in order to eliminate necrotic tissue [7]. This system intervenes in stress response through pro-inflammatory mediators produced by macrophages resident in tissues, especially the muscles, and T lymphocytes. Some of these mediators, such as interleukin 6 (IL-6), exert local actions in damaged tissues when they are produced in high amounts, as is the case in intense exercise [1]. They can also amplify the signal at the systemic level, generating the acute phase response to tissue damage and participating in the stimulation of the neuro-endocrine system through pathways parallel to the hypothalamic-pituitary-adrenal axis, in reactions that are sometimes disproportionate and harmful [1,12]. An increase in the synthesis of the hormones creatinkinase (CK), glutamic oxaloacetic transaminase (GOT) and glutamic-pyruvic transaminase (GPT) indicate recent muscle damage and the addition of external antioxidant substances can reduce their production [13].

Aware of the critical role played by inflammation in eccentric exercise-induced muscle damage, researchers have long focused on containing and reducing inflammatory responses by pharmaceutical, physical and nutritional means [14]. In this respect, dietary antioxidants are useful to stabilise free radicals and the ROS produced by oxidative stress during physical exercise [8]. They also contribute to optimising the adaptive response of biological systems to physical exercise [2]. An immunomodulator can be defined as a substance that alters the immune response, either increasing or decreasing the ability of the immune system to produce specific serum antibodies or sensitised cells that recognise and react with the antigens that initiate their production. Some of these substances are natural and others are of pharmacological origin [1].

One such dietary antioxidant is vitamin $C$, which interacts directly with free radicals and reduces the lipid peroxidation that can damage the cell membrane [8,15]. Lipid peroxidation may also be decreased by vitamin E. Both of these vitamins act as direct antioxidants, regulating REDOX levels through the elimination of ROS [8]. However, a wide variety of immunomodulatory substances with antioxidant capacities are currently used as oral supplementation, some of which are analysed in this review.

Coenzyme $\mathrm{Q}_{10}(\mathrm{Co} \mathrm{Q})$, also know as ubiquinone, is a fatsoluble benzoquinone found in most eukaryotic cells. This molecule participates in the electron transport chain producing ATP, hence its powerful antioxidant and cellular protective role [16]. Melatonin, a hormone synthesized by the pineal gland, has antioxidant properties that include scanvenging for free radicals and regulating the activity of antioxidant enzymes [17]. Another substance that could counteract the negative effects of physical exercise is oats (Avena sativa) as they may have a protective effect against cell apoptosis caused by oxidative stress [18-20].

In view of these considerations, the aim of the present study is to determine recent advances regarding antioxidant effects of different oral substances after performing muscle strength exercises that induce an increase in markers of oxidative stress and muscle damage (IL-6, CK, GOT) [1,13].

\section{Materials and Methods}

The Preferred Reporting Items for Systematic Review and Meta-Analyses guidelines (PRISMA) were used. The databases used were Web of Science, Medline, PubMed and SportDiscus. 


\subsection{Study Search}

Two authors (C.C.-G. and I.M.G.-R) conducted the search. The databases used were Web of Science, MedLine, PubMed and SportDiscus in English and Spanish. The search dates were limited to the period 1 January 2011 to 1 January 2021. The search strategy followed was: ("Antioxidant" OR "Antioxidant Effects" OR "Antioxidant Supplements" OR "Nutrition Supplementation" OR "Anti-Oxidants" [All Fields]) AND ("Resistance Training" OR "Strength Training" OR "Eccentric Exercise" OR " Eccentric Training" OR "Concentric Exercise" OR "Concentric Training" OR "Isometric Training" OR "Isometric Exercise" OR “Muscle Strength" OR "Isokinetic Training" OR "Isokinetic Exercise" OR "Weight Bearing Exercise" [All Fields]) AND ("Inflammation" OR "Muscle Weakness" OR "Muscle Damage" OR "Muscle Fatigue" OR “Oxidative Stress" OR "Oxidative Stresses" [All Fields]).

\subsection{Eligibility Criteria}

Articles that met the following criteria were included in this review: (I) randomised control study (RCT) design, (II) dietary supplementation included oral antioxidant substances, (III) only studies that used resistance training and aerobic exercises as a form of intervention were included. Studies that met the following criteria were excluded: (I) published in a language other than English or Spanish; (II) full access to the text and conference presentations, theses and books were not contained; they were duplicates, editorials, review papers or expert opinions; (III) the primary and/or secondary authors of the articles did not respond to email requests to provide missing and required information.

\subsection{Study Selection}

After an initial screening for our inclusion and exclusion criteria and the removal of duplicates (C.C.-G. and I.M.G.-R.), three reviewers independently assessed the articles by screening abstracts (C.C.-G., D.J.-M. and I.M.G.-R.). Next, the full text of each article was obtained and screened against the exclusion criteria. Any disagreement between them was resolved through discussion or the intervention of an arbitrary third investigator was requested. After this first stage, the previously selected articles were read in full. Subsequently, the selected articles were evaluated by two researchers (C.C.-G. and I.M.G.-R.) to review the evaluation of methodological quality using the PEDro scale.

\subsection{Data Extraction}

An Excel form was used for data extraction. Of each manuscript selected for review, the following information was considered: study, sample, participants, training methodology, supplementation, method, administered doses, measurements, results.

\subsection{Assessment of Methodological Quality}

The quality of the evidence of the articles included in this review was assessed using the PEDro scale, which is based on criteria that identify whether RCTs have sufficient internal validity and statistical information to interpret the results (external validity (Item 1), internal validity (Items 2-9) and statistical reporting (Items 10-11). Each item is classified as yes or no ( 1 or 0$)$ according to whether the criterion is clearly met in the study. The total score is from Item 2 to 11 , so the maximum score is 10 . Two independent investigators (C.C.-G. and I.M.G.-R.) evaluated the articles using this scale. In case of discrepancy, a third evaluator (D.J.-M.) was consulted.

\subsection{Stadistical Analysis}

The agreement rate between the reviewers for the quality assesment of the studies was calculated using kappa statistics. Agreement was assessed as proposed by Landis and Koch (1977), with 0.8 to 1.0 indicating almost perfect agreement, 0.6 to 0.8 substantial, 0.4 to 0.6 moderate, 0.2 to 0.4 fair, zero to 0.2 slight and zero or lower poor. The software package 
used was SPSS statistics (IBM Corporation, Armonk, NY, USA) and the result was 95\% agreement-almost perfect (Table 1).

Table 1. Interpretation of Kappa Statistic.

\begin{tabular}{cc}
\hline Kappa Statistic & Strength of Agreement \\
\hline$<0.00$ & Poor \\
$0.00-0.20$ & Slight \\
$0.21-0.40$ & Fair \\
$0.41-0.60$ & Moderate \\
$0.61-0.80$ & Substantial \\
$0.81-1.00$ & Almost Perfect \\
\hline
\end{tabular}

Agreement measures for categorical data.

\section{Results}

\subsection{Article Selection}

The database search identified a total of 1709 articles. After duplicate studies were eliminated, 1690 remained. In each case, the title and abstract were evaluated according to their relevance to the review criteria. Studies that were duplicates, those for which the full text was not available, those carried out with animals, those not related to the search and those based on subjects who had a pathology or injury at the time of the study were all eliminated. After applying these criteria, 31 articles remained. However, in eight there was no control group, in another ten no antioxidant was consumed, and in another seven the state of fatigue did not result from physical exertion. Finally, therefore, seven articles were selected for inclusion in this systematic review (Figure 1).

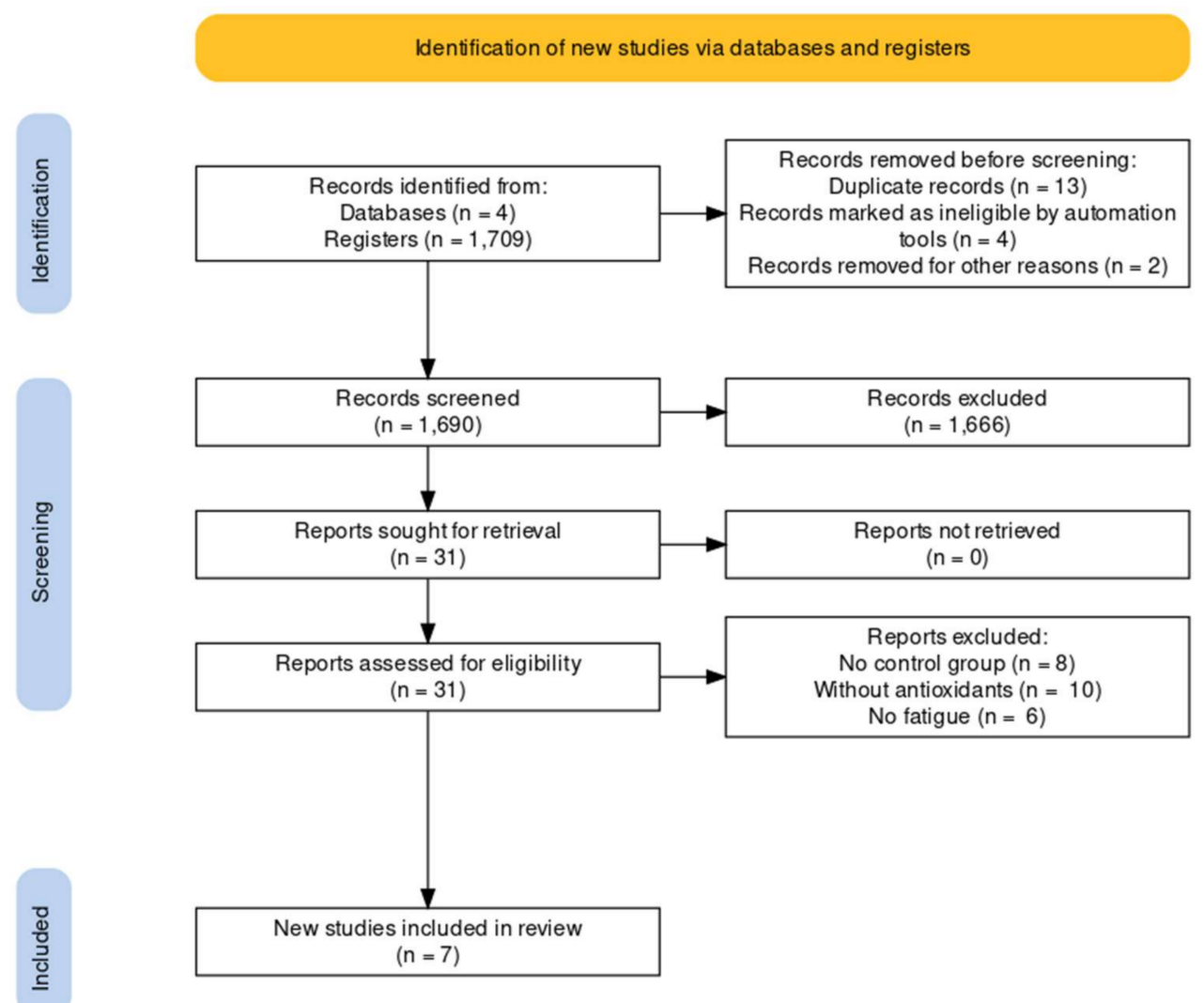

Figure 1. PRISMA flow diagram of the selection process of articles included in the systematic literature review of investigating the effect of antioxidant supplementation after a strength exercise. 


\subsection{Included Studies and Study Characteristics}

Table 2 presents the main characteristics of the included studies. Finally, seven articles met the inclusion criteria established for this review, of which only one included men and women in the study. Of the other studies, four were conducted only with men, one only with women, and another study did not specify the sex of the participants in the study sample. The age range of the participants was from $20 \pm 0.7$ years to $39 \pm 8.7$ years; the weight from $62 \pm 8 \mathrm{~kg}$ to $80 \pm 10 \mathrm{~kg}$; the height from $167 \pm 7 \mathrm{~cm}$ to $179 \pm 6.04 \mathrm{~cm}$. In the study by Thang et al. [14] weight and height were not specified; BMI and maximum heart rate results were shown. In the study by Ortiz-Franco et al. [17] and Sarmiento et al. [16] the age, weight and height are indicated both in the experimental group and in the control group.

Table 2. Characteristics of the participants of the studies selected for the review.

\begin{tabular}{|c|c|c|c|c|c|}
\hline Author (N) & $\begin{array}{c}\text { Sample Size } \\
\text { and Sex } \\
\text { (Male/Female) }\end{array}$ & Age (Mean \pm SD) & Weight (kg) & Height (cm) & $\begin{array}{c}\text { Level of } \\
\text { Condition of } \\
\text { Physical } \\
\text { Activity or Health }\end{array}$ \\
\hline Ammar et al., 2017 (9) & $9 / 0$ & $21 \pm 1$ & $80 \pm 10$ & $175 \pm 0.08$ & Physically active \\
\hline Da Silva et al., 2014 (21) & $21 / 0$ & $21 \pm 6$ & $78.2 \pm 5$ & $176 \pm 7$ & Healthy \\
\hline $\begin{array}{l}\text { Leonardo-Mendoça et al., } \\
2017 \text { (24) }\end{array}$ & $24 / 0$ & $20.3 \pm 0.71$ & $74.7 \pm 3.22$ & $176 \pm 1.83$ & Physically active \\
\hline McLeay et al., 2012 (10) & $0 / 10$ & $22 \pm 1$ & $62 \pm 8$ & $167 \pm 5$ & Physically active \\
\hline $\begin{array}{l}\text { Ortiz-Franco et al., } 2017 \\
\text { (14) }\end{array}$ & $14 / 0$ & $\begin{array}{c}\text { Placebo Group } \\
28.43 \pm 4.39 \\
\text { Melatonin Group } \\
26 \pm 6.03\end{array}$ & $78.39 \pm 6.68$ & $176 \pm 3.98$ & Physically active \\
\hline Sarmiento et al., 2016 (100) & $100 / \mathrm{NA}$ & $\begin{array}{c}\text { Placebo Group } \\
\quad 38.2 \pm 7.7 \\
\text { Ubiquinol Group } \\
\quad 38.9 \pm 8.7\end{array}$ & $74.8 \pm 9.8$ & $175 \pm 5.0$ & Physically active \\
\hline Thang et al., 2020 (24) & $11 / 13$ & $23 \pm 1.2$ & NA & NA & Healthy \\
\hline
\end{tabular}

$\mathrm{NA}=$ not available.

Table 3 presents the summary of the selected studies investigating antioxidant supplementation after strength exercise. This includes participants, training methodology, strength exercises, supplementation, method, administered doses, measurements, biochemical data and results. 
Table 3. Summary of studies investigating antioxidant supplementation after strength exercise.

\begin{tabular}{|c|c|c|c|c|c|c|c|c|c|}
\hline Study & Participants & $\begin{array}{c}\text { Training } \\
\text { Methodology }\end{array}$ & $\begin{array}{l}\text { Strength } \\
\text { Exercises }\end{array}$ & Supplementation & Method & $\begin{array}{l}\text { Administered } \\
\text { Doses }\end{array}$ & Measurements & Biochemical Data & Results \\
\hline $\begin{array}{c}\text { Ammar et al., } \\
2017\end{array}$ & $\begin{array}{c}\text { Trained at least } \\
5 \text { sessions per } \\
\text { week, } 3 \text { years of } \\
\text { weightlifting } \\
\text { experience, no } \\
\text { injuries, no } \\
\text { anti-inflammatory }\end{array}$ & $\begin{array}{c}2 \text { sets of } 3 \text { reps at } \\
85 \% \text { weightlifting } \\
\text { and } 3 \text { sets of } \\
2 \text { reps at } 90 \%\end{array}$ & $\begin{array}{l}3 \text { Olympic } \\
\text { Weightlifting } \\
\text { exercises }\end{array}$ & Pomegranate juice & $\begin{array}{l}3 \text { tablets per day } \\
\text { ( } 48 \mathrm{~h} \text { before each } \\
\text { of the sessions) }\end{array}$ & $250 \mathrm{~mL}$ or 3 tablets & $\begin{array}{c}\text { At rest and } \\
3 \text { minutes and } \\
48 \text { hours after each } \\
\text { session }\end{array}$ & $\begin{array}{c}\text { MDA, CAT, GPX, UA, } \\
\text { Tbil }\end{array}$ & $\begin{array}{l}\text { Improved } \\
\text { recovery of acute } \\
\text { and delayed } \\
\text { responses to } \\
\text { oxidative stress }\end{array}$ \\
\hline $\begin{array}{c}\text { Da Silva et al., } \\
2014\end{array}$ & $\begin{array}{l}\text { No smoking, no } \\
\text { antioxidants or } \\
\text { taurine, no } \\
\text { resistance training } \\
\text { for at least } \\
6 \text { months, no } \\
\text { injury or illness }\end{array}$ & $\begin{array}{c}\text { Eccentric exercise, } \\
\text { weight lifting for } \\
14 \text { days }\end{array}$ & $\begin{array}{l}\text { The subject's one } \\
\text { repetition } \\
\text { maximum by } \\
\text { elbow flexors and } \\
\text { extensors }\end{array}$ & Taurine & $\begin{array}{l}\text { Once daily for } \\
21 \text { days }\end{array}$ & $\begin{array}{c}50 \mathrm{mg} \text { per } \mathrm{kg} \text { mass } \\
\text { per day for } \\
21 \text { days }\end{array}$ & $\begin{array}{l}\text { Days } 16,18 \text { and } \\
21 \text { during training }\end{array}$ & $\begin{array}{c}\text { Xylenol orange, } \\
\text { protein carbonylation, } \\
\text { total thiol content, } \\
\text { superoxide dismutase, } \\
\text { CAT, GPX, TNF- } \alpha \text {, } \\
\text { IL-1 } \beta \text {, IL-10 }\end{array}$ & $\begin{array}{l}\text { Improves } \\
\text { performance, } \\
\text { reduces muscle } \\
\text { damage and } \\
\text { oxidative stress } \\
\text { but does not } \\
\text { decrease } \\
\text { inflammatory } \\
\text { response }\end{array}$ \\
\hline $\begin{array}{l}\text { Leonardo- } \\
\text { Mendoça } \\
\text { et al., } 2017\end{array}$ & $\begin{array}{c}\text { Healthy, } \\
\text { non-smokers, no } \\
\text { medication or } \\
\text { supplementation }\end{array}$ & $\begin{array}{c}8 \text { one-hour } \\
\text { sessions per week } \\
\text { (resistance, } \\
\text { weights and } \\
\text { aerobic running). } \\
\text { Total of } 10 \mathrm{~h} \text { per } \\
\text { week }\end{array}$ & $\begin{array}{c}2 \text { sessions weight } \\
\text { training }\end{array}$ & Melatonin & $\begin{array}{l}\text { For } 4 \text { weeks, } \\
\text { 30-60 min before } \\
\text { bedtime }\end{array}$ & $100 \mathrm{mg}$ per day & $\begin{array}{l}\text { Before starting the } \\
\text { study and at the } \\
\text { end of the } \\
\text { supplementation }\end{array}$ & $\begin{array}{l}\text { Glucose, total } \\
\text { cholesterol, HDL and } \\
\text { LDL cholesterol, } \\
\text { triglycerides, urea, } \\
\text { creatinine, uric acid, } \\
\text { AST, ALT, CK, LDH }\end{array}$ & $\begin{array}{c}\text { Prevents } \\
\text { extracellular and } \\
\text { intracellular } \\
\text { oxidation, } \\
\text { protection of } \\
\text { skeletal muscle } \\
\text { against oxidative } \\
\text { damage }\end{array}$ \\
\hline $\begin{array}{l}\text { McLeay et al., } \\
2012\end{array}$ & $\begin{array}{l}\text { Physically active, } \\
\text { resistance and } \\
\text { aerobic exercise } \\
\text { twice weekly, at } \\
\text { least } 1 \text { year's } \\
\text { experience, health } \\
\text { questionnaire }\end{array}$ & $\begin{array}{l}300 \text { eccentric, } \\
\text { isometric and } \\
\text { concentric } \\
\text { quadricep } \\
\text { contractions }\end{array}$ & $\begin{array}{c}300 \text { contractions of } \\
\text { the quadriceps }\end{array}$ & Blueberries & $\begin{array}{l}\text { Morning, noon } \\
\text { and afternoon }\end{array}$ & $\begin{array}{c}\text { Each smoothie } \\
\text { blended } 200 \mathrm{~g} \\
\text { blueberries (total: } \\
1 \mathrm{~kg} \text { of } \\
\text { blueberries) }\end{array}$ & $\begin{array}{c}12,36 \text { and } 60 \mathrm{~h} \\
\text { after exercise }\end{array}$ & $\begin{array}{l}\text { CK, plasma protin } \\
\text { carbonyls, plasma } \\
\text { radical oxygen species, } \\
\text { IL-6, plasma } \\
\text { antioxidant capacity }\end{array}$ & $\begin{array}{l}\text { Accelerates the } \\
\text { recovery of } \\
\text { maximum muscle } \\
\text { isometric strength } \\
\text { and regulation of } \\
\text { antioxidant } \\
\text { adaptation } \\
\text { processes }\end{array}$ \\
\hline
\end{tabular}


Table 3. Cont.

\begin{tabular}{|c|c|c|c|c|c|c|c|c|c|}
\hline Study & Participants & $\begin{array}{c}\text { Training } \\
\text { Methodology }\end{array}$ & $\begin{array}{l}\text { Strength } \\
\text { Exercises }\end{array}$ & Supplementation & Method & $\begin{array}{l}\text { Administered } \\
\text { Doses }\end{array}$ & Measurements & Biochemical Data & Results \\
\hline $\begin{array}{l}\text { Ortiz-Franco } \\
\text { et al., } 2017\end{array}$ & $\begin{array}{l}\text { Medical interview, } \\
\text { non-smoker, no } \\
\text { lactose intolerance, } \\
\text { no medication, } \\
\text { regular sleep } \\
\text { schedule }\end{array}$ & $\begin{array}{l}6 \text { sessions per } \\
\text { week of } 60-75 \text { min } \\
\text { per day (HIIT and } \\
\text { strength exercises) }\end{array}$ & $\begin{array}{l}3 \text { sets of } \\
10 \text { repetitions at } \\
70-80 \% \text { of } 1 \mathrm{RM}\end{array}$ & Melatonin & $\begin{array}{l}1 \text { daily dose before } \\
\text { exercise }\end{array}$ & 20 mg daily & $\begin{array}{l}\text { Before the start of } \\
\text { the study, } \\
\text { immediately after } \\
\text { and } 24 \mathrm{~h} \text { after the } \\
\text { physical exercise }\end{array}$ & $\begin{array}{l}\text { Glucose, urea, creatine, } \\
\text { uric acid, total } \\
\text { cholesterol, HDL, LDL, } \\
\text { Triglycerides, total } \\
\text { bilirubin, iron, } \\
\text { albumin, prealbumin, } \\
\text { transferrin, ferritin, } \\
\text { red blood cells, } \\
\text { haemoglobin, } \\
\text { haematocrit }\end{array}$ & $\begin{array}{l}\text { Improves } \\
\text { antioxidant status } \\
\text { and beneficial } \\
\text { effects on damage } \\
\text { produced by high } \\
\text { intensity training }\end{array}$ \\
\hline $\begin{array}{l}\text { Sarmiento } \\
\text { et al., } 2016\end{array}$ & $\begin{array}{c}\text { Firefighters, } \\
\text { medical interview } \\
\text { and physical exam }\end{array}$ & $\begin{array}{c}\text { Circuit of } \\
10 \text { bodybuilding } \\
\text { exercises (sports } \\
\text { press, chest press, } \\
\text { seated row, } \\
\text { shoulder press, } \\
\text { hamstring curl, } \\
\text { chest press, chest } \\
\text { step, chest } \\
\text { surveyor, push } \\
\text { with weight and } \\
\text { quadriceps } \\
\text { extension }\end{array}$ & $\begin{array}{c}\text { Chest press, } \\
\text { shoulders press, } \\
\text { femoral biceps } \\
\text { flexion, } \\
\text { quadriceps } \\
\text { extension }\end{array}$ & Coenzyme $\mathrm{Q}_{10}$ & $\begin{array}{l}\text { For } 2 \text { weeks prior } \\
\text { to the exercise } \\
\text { protocol }\end{array}$ & 200 mg daily & $\begin{array}{l}5 \text { samples in total } \\
\text { (before } \\
\text { supplementation, } \\
\text { after } \\
\text { supplementation, } \\
\text { after exercise, after } \\
24 \mathrm{~h} \text { of rest and } \\
\text { after the second } \\
\text { exercise test }\end{array}$ & $\begin{array}{c}8 \mathrm{OHdG} \text {, lipid } \\
\text { peroxides, LDL } \\
\text { oxidized, carbonyl }\end{array}$ & $\begin{array}{c}\text { Decreases } \\
\text { oxidation and } \\
\text { does not increase } \\
\text { oxidative stress }\end{array}$ \\
\hline $\begin{array}{l}\text { Thang et al., } \\
2020\end{array}$ & $\begin{array}{l}\text { Non-obese, no } \\
\text { gastrointestinal } \\
\text { problems or } \\
\text { pathologies, } \\
\text { non-consumer of } \\
\text { tobacco or alcohol, } \\
\text { not allergic to } \\
\text { oatmeal products } \\
\text { or AINEs }\end{array}$ & $\begin{array}{l}\text { 5-minute warmup, } \\
\text { then } 4 \text { series of } \\
15 \text { min downhill } \\
\text { running at a } \\
\text { gradient of }-10 \% \text {, } \\
\text { intensity } \\
\text { equivalent to } 75 \% \\
\text { of max.HR. }\end{array}$ & $\begin{array}{l}\text { Treadmill at } 75 \% \\
\text { of max.HR. }\end{array}$ & Oatmeal & $\begin{array}{l}12 \text { units daily for } \\
8 \text { weeks }\end{array}$ & $30 \mathrm{~g}$ of oatmeal & $\begin{array}{l}6 \text { samples total (at } \\
\text { rest, post test, after } \\
4,24,48 \text { and } 72 \mathrm{~h} \text { ) }\end{array}$ & $\begin{array}{c}\text { IL-6, IL-1RA, } \\
\text { sVCAM-1 cell } \\
\text { adhesion molecule, } \\
\text { G-CSF, MCP-1, CK }\end{array}$ & $\begin{array}{l}\text { Improved plasma } \\
\text { inflammatory } \\
\text { response to } \\
\text { exercise stress and } \\
\text { mitigated muscle } \\
\text { damage }\end{array}$ \\
\hline
\end{tabular}

Abbreviated biochemical data: MDA (malonaldehyde), CAT (catalase), GPX (glutation peroxidase), UA (uric acid), Tbil (total bilirubin), TNF- $\alpha$ (tumor necrosis factor- $\alpha$ ), IL-1 $\beta$ (interleukin 1- $\beta$ ), IL-10 (interleukin-10), AST (low-density lipoproteins), ALT (alainne aminotransferase), CK (creatin kinase), LDH (lactate dehydrogenase), IL-6 (interleukin-6), IL-1RA (anti-inflammatory cytokine), GCSF (col-ony stimulating factor), MCP-1 (chemotactic cytokine). 


\subsection{Methodological Quality and Risk of Bias}

Table 4 shows that of the seven articles selected for analysis, the three that scored most highly on the PEDro scale (8/10) were Ortiz-Franco et al. [17], Sarmiento et al. [16] and Zhang et al. [14]. The following criteria were met by all seven studies: the selection criteria were specified (Item 1); the allocation to the different groups was hidden (Item 3); as concerns the most important prognostic indicators, the groups were similar at baseline (Item 4); and all subjects were blinded (Item 5). With respect to Item 2 (the subjects were randomly assigned to the groups), only Ammar et al. [21] failed to meet this requirement. Item 6 (all those who administered the therapy were blinded) was only met by Da Silva et al. [22] and Ortiz-Franco et al. [17]. Item 7 (all the assessors who measured at least one key outcome were blinded) was only met by Da Silva et al. [22] and Zhang et al. [14]. Item 8 (the measures of at least one of the key results were obtained from more than $85 \%$ of the subjects initially assigned to the groups) was met by every paper except Leonardo-Mendon $\varsigma$ a et al. [23]. Item 9 (the results of all subjects who received treatment were published) was met by all studies except Ammar et al. [21] and Da Silva et al. [22]. Item 10 (between-group statistical comparisons were made and at least one key result was reported) was not met by Da Silva et al. [22], Ortiz-Franco et al. [17] or Zhang et al. [14]. Finally, Item 11 (the study included specific measures of variability for at least one key result) was met by all papers except Da Silva et al. [22] and Zhang et al. [14].

Table 4. Evaluation of the quality of evidence PEDro scale.

\begin{tabular}{ccccccccccccc}
\hline Authors & $\mathbf{1}$ & $\mathbf{2}$ & $\mathbf{3}$ & $\mathbf{4}$ & $\mathbf{5}$ & $\mathbf{6}$ & $\mathbf{7}$ & $\mathbf{8}$ & $\mathbf{9}$ & $\mathbf{1 0}$ & $\mathbf{1 1}$ & Total \\
\hline Ammar A et al. & 1 & 0 & 1 & 1 & 1 & 0 & 0 & 1 & 0 & 1 & 1 & $6 / 10$ \\
Da Silva LA et al. & 1 & 1 & 1 & 1 & 1 & 1 & 1 & 1 & 0 & 0 & 0 & $7 / 10$ \\
Leonardo-Mendonsa R et al. & 1 & 1 & 1 & 1 & 1 & 0 & 0 & 0 & 1 & 1 & 1 & $7 / 10$ \\
McLeay Y et al. & 1 & 1 & 1 & 1 & 1 & 0 & 0 & 1 & 1 & 1 & 1 & $8 / 10$ \\
Ortiz-Franco M et al. & 1 & 1 & 1 & 1 & 1 & 1 & 0 & 1 & 1 & 0 & 1 & $8 / 10$ \\
Sarmiento A et al. & 1 & 1 & 1 & 1 & 1 & 0 & 0 & 1 & 1 & 1 & 1 & $8 / 10$ \\
Zhang T et al. & 1 & 1 & 1 & 1 & 1 & 0 & 1 & 1 & 1 & 0 & 0 & $7 / 10$ \\
\hline
\end{tabular}

PEDro items: (1) Eligibility criteria; (2) Random allocation; (3) Concealed allocation; (4) Comparability at baseline (5) Patient blinding; (6) Therapist blinding; (7) Assessor blinding; (8) At least 85\% follow-up; (9) Intention to treat analysis; (10) Between-group statistical comparisons; (11) Point measures and measures of variability.

\subsection{Presentation of Results}

Regarding the sample size, Ammar et al. [21] are those with the smallest number, nine participants, and Sarmiento et al. [16] conducted the study with 100 subjects (the largest sample size). The other studies included a total of 10, 14, 21 and 24 subjetcs $[14,17,23,24]$. The mean age of the participants in the selected studies ranged from 20 years to 38.9 years. The physical fitness level of the participants was low in the studies by Da Silva et al. [22] and Thang et al. [14] — they only required their subjects be healthy. It is also in this last study that the data on the weight and height of the participants were not collected.

The studies by Mcleay et al. [24] and Ortiz-Franco et al. [17] also requested a physical examination and a medical interview. Regarding the training methodology, in each study a different kind of training was carried out for a certain time. In terms of the antioxidant supplementation used, two of the studies used melatonin $[17,23]$ and the other five all used different substances. Four blood samples were drawn in all studies except two [14,16], which made five and six measurements respectively. Two of the studies used weightlifting as the exercise [21,22], while another, in addition to this, performed an hour of endurance and aerobic running [23]. In studies that used weightlifting as the exercise, the first indicates repetitions and percentage, 2 sets of 3 repetitions at $85 \%$ and 3 sets of 2 repetitions at $90 \%$ [21]. Two other investigations used strength exercises and quadricep contractions as the sports training $[16,24]$. In the latter two, in which blueberries and Coenzyme $\mathrm{Q}_{10}$ were used as antioxidant supplements, respectively, there was an adaptation of the antioxidant processes and a regulation of oxidative stress. The study by Thang et al. [14] is the only one that used downhill running as training and they obtained an improvement in the 
inflammatory response thanks to supplementation with oatmeal. This grain can be used like an antioxidant supplement because one of the major components of polyphenolic amides (nonflavonoids) is AVA, which has beneficial effect on the organism after training [14]. The study carried out by Da Silva et al. [22], who used taurine as the supplement, found that although it reduces muscle damage it does not decrease the inflammatory response.

In the study carried out by Leonardo-Mendonsa et al. [23] with oral melatonin supplementation, skeletal muscle protection occurred after endurance training, weights and aerobic running. Iin the study by Thang et al. [14] a five-minute pre-training warm-up was mentioned, followed by four sets of fifteen minutes running downhill with a gradient of $-10 \%$. Furthermore, in the study by Ammar et al. [21] the first two sets of three repetitions at $85 \%$ and the following three sets of two repetitions at $90 \%$ involved weightlifting. This led to a better recovery of acute and delayed responses to oxidative stress.

The abovementioned antioxidant power substances with a training programme that promotes muscle damage led to the inclusion of these studies in this systematic review.

\subsubsection{Dietary Intake}

In the studies by Da Silva et al. and Leonardo-Mendoça et al. [22,23], the dietary intake of the participants was recorded for at least three consecutive days. In the first mentioned study, food intake was also recorded on the day of the test and one day after. In the study by Ortiz-Franco et al. [17], a nutritional assessment was performed by recording dietary intake for fourteen days.

\subsubsection{Blood Samples}

Two studies analysed enzymatic antioxidants (CAT, catalase and GPx, glutation peroxidase) [21,22] and the latter also analysed the antioxidant enzyme SOD, superoxide dismutase. These are not altered by taurine supplementation neither are the inflammatory enzymes (TNF- $\alpha$, tumor necrosis factor- $\alpha$, IL-1 $\beta$, interleukin-1 $\beta$ and IL-10, interleukin-10). In another study, in addition to the general analysis of markers of muscle damage and oxidative stress, lymphocytes were isolated [17]. In the study by Sarmiento et al. [16], the amount of lactate analysed increased in both groups (control and experimental) even when ubiquinol was ingested. The study by Thang et al. [14] was the only one to measure cell adhesion molecule (sVCAM-1), colony stimulating factor (G-CSF) and chemotactic cytokine (MCP-1), which used oatmeal as an antioxidant supplement.

\section{Discussion}

The aim of this study is to determine the effect of antioxidant consumption on markers of oxidative stress and muscle damage after performing muscle strength exercises. At the general level, supplementation with pomegranate juice alleviates oxidative stress, taurine reduces muscle damage, melatonin protects the skeletal muscles, blueberries decrease oxidation and oats mitigate muscle damage. In relation to high-intensity training, the results obtained cannot be grouped due to the wide diversity of the studies addressed and we did not find other studies that followed the same training protocol while incorporating different antioxidant substances. In this respect, different studies used weights as eccentric exercises [23,25-27]; however, in each of them a different training protocol was performed; increasing weight percentages in each repetition or adding another exercise to the programme $[28,29]$. Concerning design, all studies were randomized and double-blind. Selected subjects had to be physically active except for two studies that only required them to be healthy [14,29-31].

Our analysis of the studies selected highlights the benefits of oral antioxidants, which provide varying levels of improvement depending on the antioxidant used.

Substances currently used as oral antioxidant supplements could produce improvements in the body by decreasing the markers of oxidative stress or muscle damage by restoring the REDOX balance or by protecting the skeletal muscles [32-35]. 
Regular physical exercise is associated with health benefits and decreased mortality [16,36-38]. However, strenuous exercise generates oxidative stress and a pro-inflammatory state, among other negative consequences [1,38-40]. In view of the major impact of inflammation on the organism, supplementation with immunomodulatory substances would be beneficial [41-45]. Among many populations there is growing interest in regular physical exercise, often involving muscle strength training exercises [46-51]. This pattern of activity highlights the importance of incorporating antioxidant substances in the diet to counteract the possible negative effects of this exercise on the body $[17,50]$.

Among other consequences, muscular strength exercises may provoke alterations in the REDOX reactions within the immune system via the infiltration of neutrophils into the damaged tissues, leading to inflammation in the muscles and increased markers of oxidative stress $[7,8,14]$. The studies reviewed $[14,16,17,21-24]$ concerned different antioxidants examined and their effectiveness at counteracting the negative effects of muscle strength training. In the seven studies reviewed, this hypothesis was tested by associating each oral antioxidant with a specific action at the systemic level. In every case, an improvement was achieved and reflected as a decrease in the markers of muscle damage and/or oxidative stress.

In Ammar et al. [21], after pomegranate juice was used as a supplement (three tablets a day during the $48 \mathrm{~h}$ prior to each training session) improvements were recorded in the recovery from acute and delayed oxidative stress. Specifically, there was a reduction in the immediate increase in malondialdehyde (MDA), which produced a significant effect on lipid peroxidation and antioxidant parameters.

These findings corroborate Mazani et al. [49], who showed that $240 \mathrm{~mL}$ of pomegranate juice consumed daily for 14 days before using a treadmill significantly increased the activity of enzymatic antioxidants. Therefore the antioxidant properties of pomegranate juice are linked to the attenuation of lipid peroxidation responses since they lead to a reduction in acute oxidative stress. In view of these findings, it is suggested that antioxidant activities have the greatest effect immediately after intensive physical exercise, when the pomegranate juice supplementation was provided [21]. In the latter study, unlike Ammar et al. [21], the pomegranate juice was supplied in the form of tablets ingested two days before the session. Da Silva et al. [22] showed that supplementation with taurine, one tablet a day for 21 days, reduced oxidative muscle damage but not the inflammatory response. In this research, the CK parameter (a marker of skeletal muscle injury) was used to measure muscle damage after extensive exercise. The authors concluded that taurine affects vascular tone, producing vasodilation and improving blood flow and thereby reducing ischaemia and the production of ROS [22].

On the other hand, studies in which melatonin supplementation was examined observed that it helped to prevent extracellular and intracellular oxidation and protected the skeletal muscles against oxidative damage, as well as reducing the damage from high intensity training $[17,23]$. Regarding antioxidant adaptation processes, it was observed that blueberries helped regulate antioxidant adaptation processes [24,50]. Melatonin protects against muscle damage and oxidation caused by free raedicals. One of the most attractive properties of this hormone that distinguishes it from other antioxidants is that it has the ability to scavenge ROS (reactive oxygen species) and reactive nitrogen species [23]. The blueberry fruit used by Mcleay et al. has a high free radical scavenging capacity, so it would not only reduce oxidative stress but also inflammation [24].

During training, oxidation and oxidative stress could be reduced by daily coenzyme $\mathrm{Q}_{10}$ intake [16].

Additionally, studies on oat intake $[14,51]$ have concluded that this substance improved the inflammatory response of plasma and mitigated muscle damage (decreasing the CK marker in plasma), thus reducing circulatory inflammatory cytosines and inhibiting chemokine expression. Specifically, the study by Zhang et al. [14] was the only one of those reviewed that recorded the pain sensations experienced (probably related to the muscle damage induced by high intensity training). This sensation was reduced when the 
diet contained oats, which suggests that long-term oatmeal consumption provides specific protection against muscle damage and oxidative stress.

The present study has certain limitations, notably the small number of papers selected for analysis, which prevented us from examining the parameters considered in greater detail. This problem reflects the fact that, to date little research has been conducted with respect to muscle strength training [22-26]. In this respect, we believe that it would be useful to make a comparable comparison between studies if the same training protocols were used, performing the same eccentric exercises but with the same repetitions and the same intensity, differing only in the antioxidant supplements used. In this way, it would be easier to appreciate the positive effect of different oral antioxidant substances and the practice of physical exercise. Furthermore, most of the studies included in our review were based on a relatively small sample size except for the study by Sarmiento et al. [16], which included a sample of 100 subjects. As mentioned above, the fact that a different training protocol was applied in each study also prevented us from establishing a uniform research pattern. Another possible limitation is the heterogeneous dietary intake of the participants prior to the experiment and the sleep control applied (this consideration is important; according to Finan et al. [48], a lack of sleep can increase pain sensitivity and perception).

Overall, little importance was given to the dietary intake of participants during these studies, but this should be taken into account as diet and consumption of certain substances can influence the markers of oxidative stress and the effect of the antioxidants consumed.

We propose a standardized diet be provided to all participants at the start of the study so that subjects consume the same amount of proteins, fats, vitamins, etc., in a controlled manner so it does not influence the study.

With respect to sleep control, we think that it can influence how pain is perceived, but it is not very cost-effective or accurate. Therefore, it should only be taken into account when studying blood markers related to muscle damage and oxidative stress.

Among the strengths of the study is the fact that the literature search spanned the last 10 years and thus obtained up-to-date results and methodologies. Additionally, the comparison made of the effects of different antioxidants within the same study is valuable.

We invite other researchers to make use of the data presented in this review to conduct future investigations regarding the association between the intake of antioxidant substances and the impact of high intensity physical training. Our recommendations are to include the variable of high intensity training, to increase the size of the study sample, to control the participants' dietary intake prior to starting the training programme and to monitor the consumption of antioxidant substances.

\section{Conclusions}

From the results obtained, we observe that supplementation with antioxidant substances could help regulate cellular homeostasis, thus contributing to better REDOX in the skeletal muscles.

In view of these considerations, we conclude that there exists a positive relationship between the consumption of supplements with antioxidant properties and reduced cellular damage and inflammation.

Comparisons of our findings with other meta-analyses and systematic reviews addressing the question of antioxidant supplementation for persons subjected to a strenuous exercise protocol shows that there is a positive relationship between this supplementation and post-exercise recovery. In other words, the antioxidant substances ingested during a given period play a transcendental role in the subject's post-training recovery $[6,9,10,16]$. At a practical level, we also observe that the antioxidant substances examined in our research can be found in the form of tablets, which makes it easier to control the exact dose being ingested $[16,17,22,23]$. Moreover, this presentation makes the supplements readily accessible to the general population, as well as those engaged in strenuous exercise.

The findings of this systematic review indicate that there is a very low number of studies looking at muscle damage and oxidative stress while performing muscle strength 
exercises. In summary, the results of this study point to the conclusion that muscle strength exercises produce oxidative stress and that appropriate supplementation with antioxidant substances may prove to have beneficial effects, thus improving the antioxidant status and preventing muscle damage induced by strenuous exercise. Future research should assess these same variables with a larger number of participants while taking into account the variable of muscular strength exercises.

Author Contributions: Conceptualisation, C.C.-G., R.G.-B. and D.M.-G.; methodology, C.C.-G. and I.M.G.-R.; formal analysis, C.C.-G. and D.M.-G.; writing-original draft preparation, C.C.-G., R.G.-B. and I.M.G.-R.; writing-review and editing, R.G.-B., I.J.C.-R., D.J.-M. and I.M.G.-R.; visualisation, C.C.-G., D.J.-M., I.J.C.-R. and I.M.G.-R.; supervision, C.C.-G., R.G.-B., D.J.-M. and I.M.G.-R. All authors have read and agreed to the published version of the manuscript.

Funding: The researcher Isabel María Guisado-Requena received funding from the European Regional Development Fund (FEDER;2018/11744).

Institutional Review Board Statement: Not applicable.

Informed Consent Statement: Not applicable.

Acknowledgments: This paper will form part of Cristina Canals-Garzón's Doctoral Thesis being carried out within the Biomedicine Doctoral Programme of the University of Granada (Spain).

Conflicts of Interest: The authors have no conflict of interest to declare.

\section{References}

1. Gomez, M.C.; Carretero, A.; Millan-Domingo, F.; Garcia, E.; Correas, A.; Olaso, G.; Viña, J. Redox-related biomarkers in physical exercise. Redox Biol. 2021, 42, 101956. [CrossRef] [PubMed]

2. Diaz-Castro, J.; Moreno-Fernandez, J.; Chirosa, I.; Chirosa, L.J.; Guisado, R.; Ochoa, J.J. Beneficial effect of ubiquinol on hematological and inflammatory signaling during exercise. Nutrients 2020, 12, 424. [CrossRef] [PubMed]

3. Piercy, K.L.; Troiano, R.P.; Ballard, R.M.; Carlson, S.A.; Fulton, J.E.; Galuska, D.A.; George, S.M.; Olson, R.D. The physical activity guidelines for Americans. JAMA 2018, 320, 2020-2028. [CrossRef] [PubMed]

4. Simon, H.B. Exercise and health: Dose and response, considering both ends of the curve. Am. J. Med 2015, $128,1171-1177$. [CrossRef]

5. Hernández, M.C.; Pascual, A.L.C. Benefits of physical exercise in healthy population and impact on the appearance of disease. Endocrinol. Nutr. 2013, 60, 283-286.

6. Thirupathi, A.; Pinho, R.A.; Ugbolue, U.C.; He, Y.; Meng, Y.; Gu, Y. Effect of running exercise on oxidative stress biomarkers: A systematic review. Front. Physiol. 2020, 11, 1789.

7. Pappas, A.; Tsiokanos, A.; Fatouros, I.G.; Poulios, A.; Kouretas, D.; Goutzourelas, N.; Giakas, G.; Jamurtas, A.Z. The effects of spirulina supplementation on redox status and performance following a muscle damaging protocol. Int. J. Mol. Sci. 2021, 22, 3559. [CrossRef]

8. Torre, M.F.; Martinez-Ferran, M.; Vallecillo, N.; Jiménez, S.L.; Romero-Morales, C.; Pareja-Galeano, H. Supplementation with vitamins $C$ and $E$ and exercise-induced delayed-onset muscle soreness: A systematic review. Antioxidants 2021, 10, 279. [CrossRef]

9. Fang, W.; Nasir, Y. The effect of curcumin supplementation on recovery following exercise-induced muscle damage and delayedonset muscle soreness: A systematic review and meta-analysis of randomized controlled trials. Phytother. Res. 2021, 35, 1768-1781. [CrossRef]

10. Thirupathi, A.; Wang, M.; Lin, J.K.; Fekete, G.; István, B.; Baker, J.S.; Gu, Y. Effect of different exercise modalities on oxidative stress: A systematic review. BioMed Res. Int. 2021, 2021, 1947928. [CrossRef]

11. Thirupathi, A.; Pinho, R.A. Effects of reactive oxygen species and interplay of antioxidants during physical exercise in skeletal muscles. J. Physiol. Biochem. 2018, 74, 359-367. [CrossRef] [PubMed]

12. Calle, M.C.; Fernandez, M.L. Effects of resistance training on the inflammatory response. Nutr. Res. Pract. 2010, 4, 259-269. [CrossRef] [PubMed]

13. Ruhee, R.T.; Suzuki, K. Protective effects of sulforaphane on exercise-induced organ damage via inducing antioxidant defense responses. Antioxidant 2020, 9, 136. [CrossRef]

14. Zhang, T.; Zhao, T.; Zhang, Y.; Liu, T.; Gagnon, G.; Ebrahim, J.; Ji, L.L. Avenanthramide supplementation reduces eccentric exercise-induced inflammation in young men and women. J. Int. Soc. Sports Nutr. 2020, 17, 41. [CrossRef] [PubMed]

15. Popovic, L.M.; Mitic, N.R.; Miric, D.; Bisevac, B.; Miric, M.; Popovic, B. Influence of vitamin C supplementation on oxidative stress and neutrophil inflammatory response in acute and regular exercise. Oxid. Med. Cell. Longev. 2015, 2015, 295497. [CrossRef] [PubMed] 
16. Sarmiento, A.; Diaz-Castro, J.; Pulido-Moran, M.; Moreno-Fernandez, J.; Kajarabille, N.; Chirosa, I.; Guisado, I.M.; Chirosa, L.J.; Guisado, R.; Ochoa, J.J. Short-term ubiquinol supplementation reduces oxidative stress associated with strenuous exercise in healthy adults: A randomized trial. BioFactors 2016, 42, 612-622. [CrossRef]

17. Ortiz-Franco, M.; Planells, E.; Quintero, B.; Acuña-Castroviejo, D.; Rusanova, I.; Escames, G.; Molina-López, J. Effect of melatonin supplementation on antioxidant status and DNA damage in high intensity trained athletes. Int. J. Sports Med. 2017, 38, 1117-1125. [CrossRef]

18. Song, S.; Lee, Y.M.; Lee, Y.Y.; Yeum, K.J. Oat (Avena sativa) Extract against Oxidative Stress-Induced Apoptosis in Human Keratinocytes. Molecules 2021, 26, 5564. [CrossRef]

19. Talar, K.; Hernández-Belmonte, A.; Vetrovsky, T.; Steffl, M.; Kałamacka, E.; Courel-Ibáñez, J. Benefits of resistance training in early and late stages of frailty and sarcopenia: A systematic review and meta-analysis of randomized controlled studies. J. Clin. Med. 2021, 10, 1630. [CrossRef]

20. Iván, C.V.; Lily, B.C.; Stephanie, S.F.; Hunter-Echeverría, K.; Nasri, M.N.G. Effects of resistance exercise training on redox homeostasis in older adults. A systematic review and meta-analysis. Exp. Gerontol. 2020, 138, 111012.

21. Ammar, A.; Turki, M.; Hammouda, O.; Chtourou, H.; Trabelsi, K.; Bouaziz, M.; Abdelkarim, O.; Hoekelmann, A.; Ayadi, F.; Souissi, N.; et al. Effects of pomegranate juice supplementation on oxidative stress biomarkers following weightlifting exercise. Nutrients 2017, 9, 819. [CrossRef] [PubMed]

22. Da Silva, L.A.; Tromm, C.B.; Bom, K.F.; Mariano, I.; Pozzi, B.; da Rosa, G.L.; Tuon, T.; da Luz, G.; Vuolo, F.; Petronilho, F.; et al. Effects of taurine supplementation following eccentric exercise in young adults. Appl. Physiol. Nutr. Metab. 2014, 39, 101-104. [CrossRef] [PubMed]

23. Leonardo-Mendonça, R.C.; Ocaña-Wilhelmi, J.; de Haro, T.; de Teresa-Galván, C.; Guerra-Hernández, E.; Rusanova, I.; FernándezOrtiz, M.; Sayed, R.; Escames, G.; Acuña-Castroviejo, D. The benefit of a supplement with the antioxidant melatonin on redox status and muscle damage in resistance-trained athletes. Appl. Physiol. Nutr. Metab. 2017, 42, 700-707. [CrossRef] [PubMed]

24. McLeay, Y.; Barnes, M.; Mundel, T.; Hurst, S.; Hurst, R.; Stannard, S. Effect of New Zealand blueberry consumption on recovery from eccentric exercise-induced muscle damage. J. Int. Soc. Sports Nutr. 2012, 9, 19. [CrossRef]

25. Suzuki, Y.; Nagato, S.; Sakuraba, K.; Morio, K.; Sawaki, K. Short-term Ubiquinol-10 supplementation alleviates tissue damage in muscle and fatigue caused by strenuous exercise in male distance runners. Int. J. Vitam. Nutr. Res. 2020, 91, 261-270. [CrossRef]

26. Pérez, F.; Pascual, V.; Meco, J.F.; Pérez, P.; Delgado, J.; Domenech, M.; Estruch, R.; León, A.; López, J.; Sánchez, A.; et al. Document of recommendations of the SEA 2018. Lifestyle in cardiovascular prevention. Clin. Investig. Arterioscler. 2018, 30, 280-310.

27. Carrera-Quintanar, L.; Funes, L.; Vicente-Salar, N.; Blasco-Lafarga, C.; Pons, A.; Micol, V.; Roche, E. Effect of polyphenol supplements on redox status of blood cells: A randomized controlled exercise training trial. Eur. J. Nutr. 2015, 54, 1081-1093. [CrossRef]

28. Vinson, J.A.; Bose, P.; Proch, J.; Al Kharrat, H.; Samman, N. Cranberries and cranberry products: Powerful in vitro, ex vivo, and in vivo sources of antioxidants. J. Agric. Food Chem. 2008, 56, 5884-5891. [CrossRef]

29. Bowtell, J.; Sumners, D.; Dyer, A.; Fox, P.; Katya, M. Montmorency cherry juice reduces muscle damage caused by intensive strength exercise. Med. Sci. Sports Exerc. 2011, 43, 1544-1551. [CrossRef]

30. Morehen, J.C.; Clarke, J.; Batsford, J.; Barrow, S.; Brown, A.D.; Stewart, C.E.; Close, G.L. Montmorency tart cherry juice does not reduce markers of muscle soreness, function and inflammation following professional male rugby League match-play. Eur. J. Sport Sci. 2020, 21, 1003-1012. [CrossRef]

31. Leduc, C.; Jones, B.; Robineau, J.; Piscione, J.; Lacome, M. Sleep quality and quantity of international rugby sevens players during pre-season. J. Strength Cond. Res. 2019, 33, 1878-1886. [CrossRef] [PubMed]

32. Zeng, Z.; Centner, C.; Golhofer, A.; König, D. Effects of Dietary Strategies on Exercise-Induced Oxidative Stress: A Narrative Review of Human Studies. Antioxidants. 2021, 10, 542. [CrossRef]

33. Bongiovanni, T.; Genovesi, F.; Nemmer, M.; Carling, C.; Alberti, G.; Howatson, G. Nutritional interventions for reducing the signs and symptoms of exercise-induced muscle damage and accelerate recovery in athletes: Current knowledge, practical application and future perspectives. Eur. J. Appl. Physiol. 2020, 120, 1965-1996. [CrossRef]

34. Ochoa, J.J.; Diaz-Castro, J.; Kajarabille, N.; García, C.; Guisado, I.M.; de Teresa, C.; Guisado, R. Melatonin supplementation ameliorates oxidative stress and inflammatory signaling induced by strenuous exercise in adult human males. J. Pineal Res. 2011, 51, 373-380. [CrossRef] [PubMed]

35. Cardona, D.M.G.; Landázuri, P.; Zuluaga, C.F.A.; Cortés, B. Biochemical markers of oxidative stress in female volleyball players. Effect of consumption of Passiflora edulis. Retos 2021, 43, 603-612.

36. Furlong, J.; Rynders, C.; Sutherlin, M.; Patrie, P.; Katch, F.; Hertel, J.; Weltman, A. Effect of an herbal/botanical supplement on strength, balance, and muscle function following12-weeks of resistance training: A placebo controlled study. J. Int. Soc. Sports Nutr. 2014, 11, 23. [CrossRef] [PubMed]

37. Ackerman, J.; Clifford, T.; McNaughton, L.R.; Bentley, D.J. The effect of an acute antioxidant supplementation compared with placebo on performance and hormonal response during a high volume resistance training session. J. Int. Soc. Sports Nutr. 2014, 11, 10. [CrossRef]

38. Çakır-Atabek, H.; Özdemir, F.; Çolak, R. Oxidative stress and antioxidant responses to progressive resistance exercise intensity in trained and untrained males. Biol. Sport 2015, 32, 321-328. [CrossRef] 
39. Gelabert-Rebato, M.; Wiebe, J.C.; Martin-Rincon, M.; Galvan-Alvarez, V.; Curtelin, D.; Perez-Valera, M.; Habib, J.; Pérez-López, A.; Vega, T.; Morales-Alamo, D.; et al. Enhancement of exercise performance by 48 hours, and 15-day supplementation with mangiferin and luteolin in men. Nutrients 2019, 11, 344. [CrossRef]

40. He, F.; Hockemeyer, J.A.; Sedlock, D. Does combined antioxidant vitamin supplementation blunt repeated bout effect. Int. J. Sports Med. 2015, 36, 407-413. [CrossRef]

41. Hoffman, J.R.; Ratamess, N.A.; Kang, J.; Gonzalez, A.M.; Beller, N.A.; Craig, S.A. Effect of 15 days of betaine ingestion on concentric and eccentric force outputs during isokinetic exercise. J. Strength Cond. Res. 2011, 25, 2235-2241. [CrossRef]

42. Salazar Serrano, D.; Atehortúa Villada, D.; Álvarez Quintero, R.M. Importance of the Addition of Antioxidants in the Diet of the High-Performance. Ces University, Final Degree Project, Founding Library 2019. Available online: https:/ / repository.ces.edu.co/ handle/10946/4923 (accessed on 8 December 2021).

43. Taherkhani, S.; Suzuki, K.; Castell, L. A short overview of changes in inflammatory cytokines and oxidative stress in response to physical activity and antioxidant supplementation. Antioxidants 2020, 9, 886. [CrossRef]

44. Sugita, M.; Kapoor, M.P.; Nishimura, A.; Okubo, T. Influence of green tea catechins on oxidative stress metabolites at rest and during exercise in healthy humans. Nutrition 2016, 32, 321-331. [CrossRef]

45. Tsuchiya, Y.; Yanagimoto, K.; Ueda, H.; Ochi, E. Supplementation of eicosapentaenoic acid-rich fish oil attenuates muscle stiffness after eccentric contractions of human elbow flexors. J. Int. Soc. Sports Nutr. 2019, 16, 19. [CrossRef]

46. DiLorenzo, F.; Drager, C.; Rankin, J. Docosahexaenoic acid affects markers of inflammation and muscle damage after eccentric exercise. J. Strength Cond. Res. 2014, 28, 2768-2774. [CrossRef]

47. Finan, P.H.; Goodin, B.R.; Smith, M.T. The association of sleep and pain: An update and a way forward. J. Pain 2013, 14, 1539-1552 [CrossRef]

48. Mazani, M.; Fard, A.S.; Baghi, A.N.; Nemati, A.; Mogadam, R.A. Effect of pomegranate juice supplementation on matrix metalloproteinases 2 and 9 following exhaustive exercise in young healthy males. J. Pak. Med. Assoc. 2014, 64, 785-790.

49. Fernández, D.; Mielgo, J.; Seco, J.; Córdova, A.; Caballero, A.; Fernández, C.I. Modulation of exercise-induced muscle damage, inflammation, and oxidative markers by curcumin supplementation in a physically active population: A systematic review. Nutrients 2020, 12, 501. [CrossRef]

50. Shang, H.; Bhagavathula, A.S.; Aldhaleei, W.A.; Rahmani, J.; Karam, G.; Rinaldi, G.; Yuan, Q. Effect of propolis supplementation on C-reactive protein levels and other inflammatory factors: A systematic review and meta-analysis of randomized controlled trials. J. King Saud Univ.-Sci. 2020, 32, 1694-1701. [CrossRef]

51. McAnulty, L.S.; Nieman, D.C.; Dumke, C.L.; Shooter, L.A.; Henson, D.A.; Utter, A.C.; Milne, G.; McAnulty, S.R. Effect of blueberry ingestión on natural killer cell counts, oxidative stress, and inflammation prior to and after $2.5 \mathrm{~h}$ of running. Appl. Physiol. Nutr. Metab. 2011, 36, 976-984. [CrossRef] 